\title{
A Review of Technological Tools in Teaching and Learning Computer Science
}

\author{
Qurat-ul-Ain ${ }^{1}$, Farah Shahid ${ }^{1}$, Muhammad Aleem ${ }^{1 *}$, Muhammad Arshad Islam 1, \\ Muhammad Azhar lqbal ${ }^{1}$, Muhammad Murtaza Yousaf ${ }^{2}$ \\ ${ }^{1}$ Department of Computer Science, Capital University of Science and Technology Islamabad 44000, PAKISTAN \\ ${ }^{2}$ Punjab University College of Information Technology, University of the Punjab Lahore, PAKISTAN
}

Received 22 August 2018 - Revised 23 March 2019 • Accepted 2 April 2019

\begin{abstract}
The technology works as a catalyst through which many changes occur in the learning approaches, teaching methodologies, research arena, in the work environment and in the use of information and knowledge. Helping students to learn using technological tools rather than using conventional techniques has become more popular in the $21^{\text {st }}$ century in colleges and schools in the domain of computer science. Integration of technological tools will help teachers to the international requirement to use technology-based teaching and learning tools instead of traditional teaching methods. Most researchers agree on the significance of the use of technological tools in different education systems. However, current state-of-the-art depicts that there is no comprehensive study that provides an analysis of different technological tools e.g. computer-based, games based, mobile based, and multimedia technologies used in education. This paper provides a comprehensive review of several of the most popular teaching methodologies (collaborative, active learning, problem-based, inductive teaching method) and technological tools i.e. computer-based (ICT, CAI, CBI), games based (serious games, web games, micro-games, videos games), mobile based (laptop, PDAs, tablets, mobile phones), online learning tools (flipped classroom, web MOOCs) and multimedia technologies (Videos, MCMs, MAMCM). The purpose of this research paper is to scrutinize the roles and effectiveness of technological tools in teaching and learning process and it provides the definition of each method, along with the similarities and differences among these teaching methodologies and technological tools. Even though the strength of each individual method is something that is met with varying degrees of evidence, teaching with the help of technological tools has been found to be generally more effective or at least equally effective to traditional methods of teaching. The purpose of the use of technology in teaching and learning process is to improve productivity, the effectiveness of current practices and bring pedagogical changes which are beneficial for the betterment of education. We explore the theoretical literature available about the influence of technology and its effectiveness in the field of education. In teaching and learning process, the use of technological tools increases interaction between teachers and students. To incorporate technology, educators and teachers must implement the right technological tools to make the environment more innovative for the students.
\end{abstract}

Keywords: education, effectiveness, information communication, technology, multimedia, technology, technological tools

(C) 2019 by the authors; licensee Modestum Ltd., UK. This article is an open access article distributed under the terms and conditions of the Creative Commons Attribution License (http://creativecommons.org/licenses/by/4.0/).

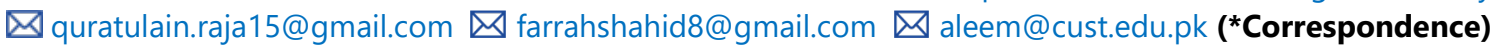




\section{Contribution of this paper to the literature}

- To explores literature related to technological tools (such as ICT, CAI, etc.) and to analyze their effectiveness in teaching and learning process for computer science.

- To provide a comprehensive review of teaching methodologies (such as collaborative, active learning, problem-based, inductive method, etc.) and their implication in the learning process.

- To gauge the usage scenario of online learning tools (flipped classroom, web MOOCs, etc.) and multimedia technologies (Videos, MCMs, etc.).

\section{INTRODUCTION}

We are residing in an ever-changing world where new developments are regularly taking place especially in the areas of Information and Communication Technology (ICT). The thirst to attain more knowledge and to imply it creatively is directly affecting not just the society and culture but also the political arena of the world (Malek, Hall, \& Hodges, 2014). Today, there is an increased pressure on education to respond to a technology-driven society and the broad use of technological tools i.e., ICT, mobile technology, and multimedia technology, etc. The role of technology in teaching is very significant because the use of technological tools improves the quality of education. Learning and teaching with the help of technological tools is an organized way of conceptualizing the execution and evaluation of the education system (Richey, Silber, \& Ely, 2008).

According to Prensky, (2008) technology can improve teaching and learning process through different ways, for instance: with greater enthusiasm by learners, enriched communication skills, assessable to learners of all levels and capabilities, excellent research tool, good assessment tools, better preparation of students for education. Computer science is a domain that always has grand expectations when it comes to producing positive outcomes and hence it faces immense pressure to adapt and evolve regularly. In the Computer science program, it is a teacher's responsibility to motivate students to identify different resources, research centers, and databases for infotainment applications. In lesson planning, teachers should use a wide range of audio videos aids and help students in order to determine themselves the skills, knowledge, and sources which are required for the completion of the learning process. A teacher should integrate sources and research skills in proper lessons for students that are based on practical labs, projects, and assignments because it is essential for the students of computer science to clarify the theoretical concepts of computer science through practical implementation. Practical skills can help learners to create the capabilities required for the present globalization. Melhuish, and Falloon, (2010) stated that to keep up with the rapid developments (e.g., development of cloud-based computing supports, M-learning), the citizens of information-age societies are expected to possess certain qualities. critical thinking, problem-solving ability, collaborating with others, communicative ability, ability to make use of different technological tools, the courage to strike novel ideas, and the determination to give rise to diversity in different learning situations. According to Alves, Schmidt, Carthcat, and Hostins, (2015), technology provides a wide spectrum to learn and possesses an enormous power to alter traditional pedagogical environments.

According to Weaver, and Sturtevant, (2015) suggesting innovative educational practices have become obligatory because it forms the foundation that prospers the growth of students belonging to the computer science domain. Various scholars have proposed the idea of transition to a modern educational environment rather than restricting to the traditional setup because this way students would learn to contribute and become active participants hence adding up to building a nurturing environment (Altbach et al., 2009; Vlieghe, 2014). According to Wrzesien, and Raya (2010), ICT not just modifies the social behaviors of students but also teaches them in several ways to interact in a social environment by instilling different values in them. Robin (2008) stated that the research conducted to devise the impact of ICT in educational setups have been proven to bring about a remarkable change in the intellectual growth of students because of its effectiveness. Hussain et al. (2011) expressed that ICT can potentially equip students for the challenges of the 21st century. Students can build up the competencies required to survive in the globalized world with the proper knowledge and understanding of ICT. ICT aids in skilldevelopment, motivation, knowledge enlightenment and it opens doors to a vast variety of knowledge. For example, the Internet can help in the training of students and providing them with the skills that will surely be needed when they go into a professional workplace e.g. email, word processing, etc. (Gulbahar, \& Guven, 2008).

The shift in deploying new technological and pedagogical approaches in tertiary education is both exciting and daunting (Arfstrom et al., 2013). Amirault (2015) stated that the most evident thing that has become absolutely palpable now is the usefulness of integration of technology and active learning into the curriculum. Neil Fleming's stated that VARK (Visual, Aural, Read/Write, Kinesthetic) design have designated that learners learn in a different way (Al-Khazl Fatimah et al. 2017). According to V. Marcy (2017), in a conventional lecture atmosphere, learners only pay attention to a trainer without any connections in the session; therefore, it is easy for them to be tired and 
bored. It has been indicated that students' attention period during a session expands up to the only quarter of an hour. According to Bakar and Mohamed (2008) incorporation of technology and knowledge in education represents the use of computer-based methods for teaching that incorporate into everyday classroom educational procedure. The use of technology offers powerful and practical teaching-learning environment. Ghavifekr et al. (2015) stated that the objective of integration of technology and information is to enhance the quality, cost-efficiency, and availability of the distribution of knowledge to learners. The use of technological innovation tools in education and learning will lead to efficient studying and students will be able to learn better within the technology-based atmosphere. Gulbahar and Guven (2008) stated that the procedure for implementing computer-based instruction is not a single step, but it is a continuous ongoing step by step process that fully supports study and education.

In this era of technology, there are numerous ways and techniques available for incorporating technology into the learning process. Having a comprehensive view of all these options, as is presented in this paper, will help the teachers in deciding the pros and cons of each method. They can then decide which option looks more promising according to their unique educational and cultural environment. According to Vlieghe (2014), today the use of technological tools in education and their remarkable effects on student's achievement is a great upturn for students in the preparation of their future career. Hussain et al. (2011) stated that in order to reach diversity in learning styles, the integration of technology into the classrooms proves very beneficial. The use of advanced technology changes the traditional way of passive learning and provides a chance for students to interact with classmates by encouraging collaboration. Moreover, the authors support that technology modifies the role of teacher and student. A teacher plays a role of encourager, adviser or coach and students can have access to digital books which are updated, creative, and cheaper and proves to be more beneficial and helpful as compared to heavy old books. Neo, and Neo (2009), stated that computers, multimedia, mobile devices, videos, web games, and Internet refined the standard of education and make learning more relevant to life and have been seen as an ideal by educational institutions. Many studies have shown the advantages of using technology in classroom instruction. Technological tools use can enhance problem-solving abilities and creativeness in students. They can be used as a tool for establishing meaningful projects to engage students in critical thinking and problem-solving. With the help of technological tools, the classrooms can be restructured and redesign to develop an environment that stimulates the development of higher-order thinking skills (Kurt, 2010). This article explores literature that describes the use of technological tools (i.e., Information Communication and Technology (ICT), Computer Assisted Instruction (CAI) Computer-Based Instructions (CBI), Game-based Learning, Collaborative Learning Approaches, Multimedia Approaches, and Mobile Technology, etc.) in learning and teaching Computer Science.

The article follows with related research discussing the technological tools used for teaching computer science. Section 2 provides a comprehensive review of the pedagogical literary work on the use of technological tools in computer science education. Section 3 summarizes the study with some concluding thoughts on the effectiveness of technological tools used in teaching computer science.

\section{TECHNOLOGY USE IN EDUCATION}

Technology has been a growing force in education, business, and private life of humans. According to Laferrière Hamel and Searson (2013), the technology used in the area of education is a blend of procedures and various tools that work together and portray the growing needs for ICT. According to Kim and Kim (2017), students find the use of technology particularly helpful when it relates directly to their course. or when they are learning about abstract concepts. However, integrating technology into classrooms for reaching new goals related to education often challenges teachers with potential difficulties because of the limited policy and pedagogical support (Kumbargoudar, 2013).

According to Chen et al. (2009), incorporating technology and making it part of the educational environment is one of the foremost responsibilities of educators and instructors. Vanderlinde and Van Braak, (2011) articulated three main directions to bring novelty into the education system 1) to make use of the content that can be acclimatized 2) to integrate different teaching skills 3) to get rid of age-old concepts. The modern requirement to question the insights has been stressed by many scholars. The authors emphasized that cognizance from the people who are the users of new technological tools is important for forecasting the efficiency of incorporation in educational setups. Not only this but the educators' perceptions and insights towards creativity should be observed. Clark et al. (2013) drew the conclusion that incorporating creative technological tools in the educational setups automatically calls for the educators to learn new skills and practices related to it. Karsenti et al. (2013) stated that it has been identified that numerous educators and instructors only use the technological tools to present the material in a digital form and barely focus its intellectually nurturing approach. Karsenti and Fievez, (2013) survey showed that prior to the experimental program $70.2 \%$ of teachers had never or very rarely' used any kind of technological tool. It also showed that $14.5 \%$ had used ICT in the class 'sometimes' and $15.2 \%$ regularly used technological tools in class. The abovementioned facts bring to light the importance of equipping the teachers with effective methods with which they can add technological tools into their teaching routine. To integrate technological 


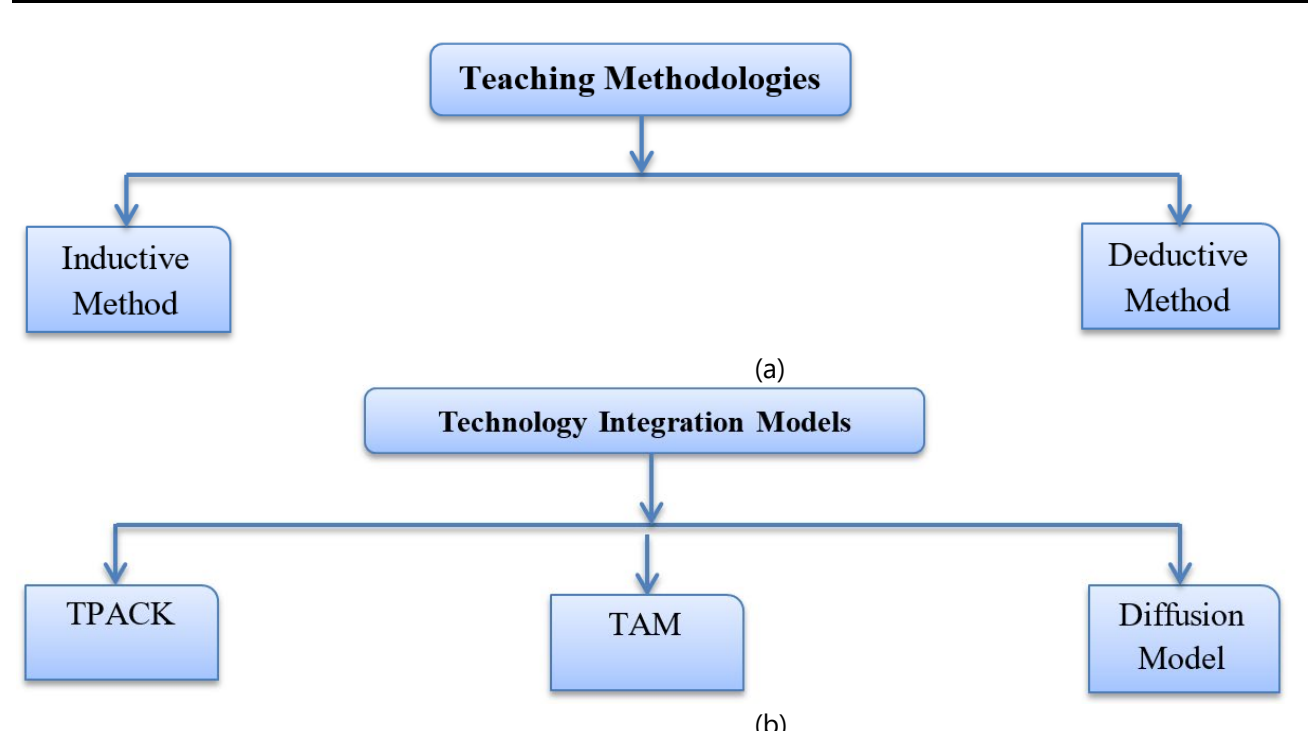

Figure 1. (a) Teaching methodologies; (b) Technology Integration Model

tools into their teaching practice the TAM (technology acceptance model) and TPACK (technological pedagogical content knowledge) models have been widely used to explore educators' apparent perceptions and to make it easy for them the use of technology. Many existing studies (Bissell, 2015; Cowan et al. 2013; and Liaw \& Huang, 2015) have theorized the integration of mobile technologies in the framework of activity theory. However, there are limitations to the use of the TPACK framework in explaining the dynamic nature of teachers' knowledge construction and experiences of practice in technology-rich environments (Koehler, et al. 2014, 2017) Olofson et al. (2016) stated that the Technology Acceptance Model (TAM) is a concept that designs how students come to agree to use a technology. Generally, TAM concept was developed to evaluate the efficiency or success of technology in assisting to understand the value and efficiency of a particular system.

\section{Technology Integration in Teaching Methodologies}

Xin (2012) said that there are two techniques of teaching methodologies; inductive and deductive as shown in Figure 1(a). Most of the times, teaching can contain both of these techniques. From a practical point of view, it can be concluded that teaching and learning are never purely either inductive or deductive. Similar to the scientific method, learning moves in both directions. The student infers theories and rules based on what $\mathrm{s}$ (he) observes (induction). Student tests the theories, and experiments to verify the consequences and applications of the theories (deduction). An ideal teaching method must be able to help students learn to do both.

Rahmatianand Zarekar (2016) described an inductive method instructor will deliver the lecture with a wide range of examples for a given idea without providing any preamble about how the idea is used. Malek et al. (2014) stated that the deductive way of teaching is a more teacher-centered strategy. This means that the instructor gives learners a new idea. For instance, when an instructor delivers a new idea to the students s(he) will introduce the basic concepts, describe the guidelines related to its use, and lastly, learners will exercise using the concept in different ways.

TPACK and diffusion models are the three most widely used models for technology integration in education as shown in Figure 1(b). Koh et al. (2015) stated that TAM and TPACK models have been used for various purposes such as 1) to make the technology useless intricate, 2) to examine the perception and understanding of the instructors and teachers, 3) to analyze the educational content and ways of instructing the knowledge. The TAM concept consists of various parts which comprise the process of acceptance of ICT, behavior intention, recognized efficiency, and simplicity of use. Koehler et al. (2017) stated that TPACK defines the connections weaved between the information related to technology, the content that is being taught and the way things are being taught. To develop a deeper connection between ICT and a good educational environment for students, there lies a responsibility for teachers. They are expected to motivate the students and help them deal with the problems that are real.

Roger (2004) asserted that the purpose of the integration of ICT to improve quality studying and educating experience in educational institutions implies a succession of various physical mediums of transmission such as communication channels. According to Roger's diffusion model, the course of embracing the new developments in technology involves different procedures. The procedure will begin with first state knowledge that symbolizes decision making features of the unit by the ICT users to incorporate the technology. The procedure ends with the 
Table 1. Teaching methodologies and technology integration models taxonomy

\begin{tabular}{|c|c|c|c|c|c|}
\hline \multirow[b]{2}{*}{ References } & \multicolumn{2}{|c|}{ Teaching Methodologies } & \multicolumn{3}{|c|}{ Technology Integration Models } \\
\hline & $\begin{array}{l}\text { Inductive } \\
\text { Method }\end{array}$ & $\begin{array}{c}\text { Deductive } \\
\text { Method }\end{array}$ & TAM Model & $\begin{array}{l}\text { TPACK } \\
\text { Model }\end{array}$ & $\begin{array}{c}\text { Diffusion } \\
\text { Model }\end{array}$ \\
\hline Rogers (2004) & $\mathrm{x}$ & $\mathrm{x}$ & $\mathrm{x}$ & $\mathrm{x}$ & $\checkmark$ \\
\hline Malek, Hall, and Hodges (2014) & $\checkmark$ & $\checkmark$ & $\mathrm{x}$ & $\mathrm{x}$ & $\mathrm{X}$ \\
\hline Rahmatian, and Zarekar (2016) & $\checkmark$ & $\checkmark$ & $\checkmark$ & $\mathrm{x}$ & $\mathrm{X}$ \\
\hline Davies, and Cormican (2013) & $\checkmark$ & $\checkmark$ & $\mathrm{X}$ & $\mathrm{X}$ & $\mathrm{X}$ \\
\hline Knutas, Herala, Vanhala, and Ikonen (2016) & $\checkmark$ & $\checkmark$ & $\mathrm{X}$ & $\mathrm{x}$ & $\mathrm{X}$ \\
\hline MacNeil, Latulipe, Long, and Yadav (2016 & $\mathrm{X}$ & $\mathrm{x}$ & $\mathrm{X}$ & $\mathrm{X}$ & $\mathrm{X}$ \\
\hline Wang, DeMaria Jr, Goldberg, and Katz (2016) & $\checkmark$ & $\checkmark$ & $\mathrm{x}$ & $\mathrm{x}$ & $\mathrm{x}$ \\
\hline Xin (2012) & $\checkmark$ & $\checkmark$ & $\mathrm{X}$ & $\mathrm{X}$ & $\mathrm{x}$ \\
\hline Ghavifekr, and Rosdy (2015) & $\checkmark$ & $\checkmark$ & $\checkmark$ & $\mathrm{x}$ & $\checkmark$ \\
\hline Sallee, Edgar, and Johnson (2013) & $\checkmark$ & $\mathrm{X}$ & $\mathrm{X}$ & $\mathrm{x}$ & $\mathrm{X}$ \\
\hline Chiou, Tien, and Lee (2015) & $\checkmark$ & $\checkmark$ & $\mathrm{x}$ & $\mathrm{x}$ & $\mathrm{X}$ \\
\hline Mason, Shuman, and Cook (2013) & $\checkmark$ & $\checkmark$ & $x$ & $x$ & $\mathrm{X}$ \\
\hline Lavelle, Stimpson, and Brill (2015) & $\checkmark$ & $\checkmark$ & $\mathrm{X}$ & $\mathrm{X}$ & $\mathrm{X}$ \\
\hline Koehler, Greenhalgh, Rosenberg, and Keenan (2017) & $\checkmark$ & $\mathrm{x}$ & $\checkmark$ & $\checkmark$ & $\checkmark$ \\
\hline Kearney, and Maher (2013) & $\mathrm{x}$ & $\mathrm{x}$ & $\checkmark$ & $\checkmark$ & $\mathrm{x}$ \\
\hline Koh, Chai, Benjamin, and Hong (2015) & $\mathrm{x}$ & $\mathrm{x}$ & $\mathrm{x}$ & $\checkmark$ & $\mathrm{x}$ \\
\hline Olofson, Swallow, and Neumann (2016) & $\mathrm{x}$ & $\mathrm{x}$ & $\checkmark$ & $\checkmark$ & $\mathrm{x}$ \\
\hline
\end{tabular}

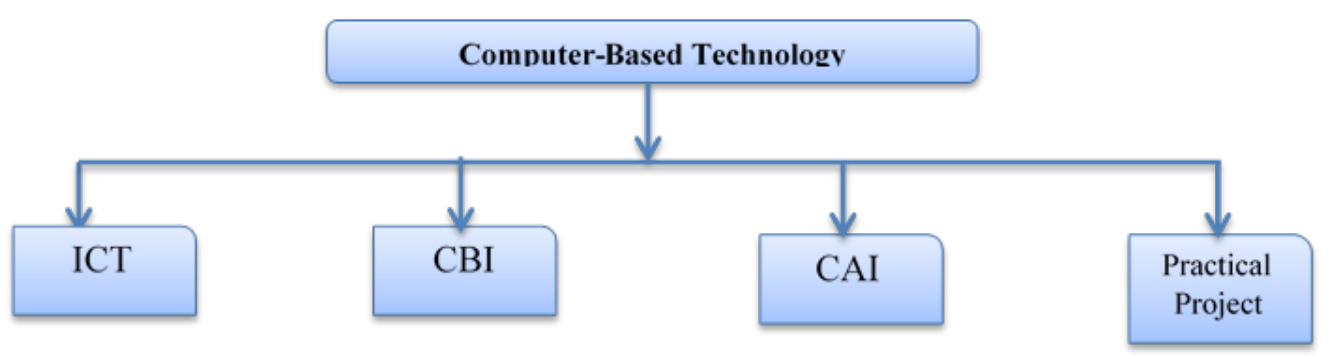

Figure 2. Computer-based technological tools

approval of the users to agree to use technology. Integrating and making solid use of technology in educational setups confirms the fulfilling application of creative approaches and develops an understanding among different people belonging to the same community.

Table 1 presents the teaching methodologies (inductive method and deductive method) and technology integration models (TAM, TPACK, and diffusion model (Rogers, 2004)).

\section{Computer-based Technology}

Computer-based training is any prospectus in which learners interact with a personal computer as a key factor of the studying process. Figure 2 shows the different computer-based technological tools. According to Malek et al. (2014), the use of ICT contains various aspects which are associated directly with the primary aim of the research that describes how the use of technological tools will impact the professed efficiency and convenience. The objective of instructors to use technological innovation is highly affected by their views on the efficiency of the system as well as the recognized convenience of use and decides their actual use of ICT. In another study, Gulbahar and Guven (2008) stated that the CBI is an educating strategy that combines software application programs with other educating components in the classroom. DeMaria et al. (2016) stated that CAI programs use academic video sources are a great way to add visual inducements in lessons. CAI programs are not the replacement of lectures; however, can be used as an extension of the lecture. In another study, Sallee Edgar and Johnson (2013) stated that CAI refers to simulation or tutorial, activities practice, and drill, which offered enhancements to customary teacher concentrating instruction. CAI is more efficient when used as a complement to conventional teaching. The influence of implementation of CAI on the learners' minds proves that it has the ability to assist students by providing them a framework in which they would build and interact and learn. 
Table 2. Use of Computer-based technologies in education

\begin{tabular}{|c|c|c|c|c|c|}
\hline \multirow[b]{2}{*}{ Reference } & \multicolumn{5}{|c|}{ Computer-Based Technology } \\
\hline & ICT & CBI & CAI & Web & $\begin{array}{c}\text { Practical } \\
\text { Project }\end{array}$ \\
\hline Ghavifekr, and Rosdy (2015) & $\checkmark$ & $\checkmark$ & $\checkmark$ & $X$ & $\checkmark$ \\
\hline Bakar, and Mohamed (2008) & $\checkmark$ & $\checkmark$ & $\checkmark$ & $\mathrm{x}$ & $\checkmark$ \\
\hline Vanderlinde, and Van Braak (2010) & $\checkmark$ & $\checkmark$ & $\checkmark$ & $\mathrm{X}$ & $\mathrm{X}$ \\
\hline Vanderlinde, and Van Braak (2011) & $\checkmark$ & $\checkmark$ & $\checkmark$ & $x$ & $x$ \\
\hline Sallee, Edgar, and Johnson (2013) & $\mathrm{X}$ & $\mathrm{x}$ & $\checkmark$ & $\mathrm{X}$ & $\mathrm{x}$ \\
\hline Malek, Hall, and Hodges (2014) & $\checkmark$ & $\mathrm{x}$ & $\mathrm{x}$ & $\checkmark$ & $\checkmark$ \\
\hline Wang, DeMaria Goldberg, and Katz (2016) & $\checkmark$ & $\mathrm{x}$ & $\checkmark$ & $\checkmark$ & $\mathrm{X}$ \\
\hline Mason, Shuman, and Cook (2013) & $\checkmark$ & $\checkmark$ & $\checkmark$ & $\checkmark$ & $\checkmark$ \\
\hline Lavelle, Stimpson, and Brill (2015) & $X$ & $X$ & $X$ & $X$ & $\checkmark$ \\
\hline
\end{tabular}

In Mason et al. (2013) opinion, CBI basically refers to any kind of computer use in educational settings which includes simulations, tutorials, programming, databases, drill, practice, supplementary exercises, writing using word processor, or other applications and these terms may refer to either computer activities which are taught by teachers in classroom through reinforcement or to stand-alone computer learning activities. According to Ghavifekr et al. (2015) Integration of ICT in education and learning pertains to the use of computer-based communication that integrates into everyday classroom educational procedure. ICT has the capability to provide powerful and practical teaching-learning atmosphere. Bakar et al. (2008) mentioned that the incorporation of ICT in education generally means technology-based studying and educating procedure. A comprehensive model purposed by Vanderlinde et al. (2011) highlights that because of the various areas related to incorporating the technology, it is known as an Ecapacity model. The model E-capacity refers to the ability of a school to create and optimize conditions at the school and the teacher level, to bring effective ICT change. Vanderlinde et al. (2010), the definition of E-capacity provided in the school improvement literature, has been tailored and translated for the case of ICT integration. The E-capacity of a school, defined as the communal capability of a school to contrivance ICT in a way that is a lever for change in teaching and learning. From this perception, e-capacity is about creating and optimizing maintainable teacher and school level conditions to foster effective amendments with the help of ICT. Here, ICT serves as a pedal to bring a pedagogical reform and is usually affected by the educator who has to employ that in the educational set up and has the position to employ it in for several areas such as for the sake of learning or for the sake of providing knowledge about something. Certain conditions are applied to the educators who are related to ICT, for example, the educator's ability to put up with the technological tools and professional growth. Moreover, numerous resources are required for it, for example, assistance and a framework where all those tools could be employed.

Lavelle et al. (2015) research outline the contemporary uses of technological tools in teaching and learning practices. Authors stated that the convenience and accession to the World Wide Web and other areas pertaining to interaction are a few aspects that represent and portray the change that has happened over the years in the field of learning.

\section{Multimedia Technology as an Educational Resource}

According to Davies et al. (2013), multimedia components are preferred by many teachers at present. The multimedia animations consist of images, words, sounds, pictures, and moving images. Figure 3 shows the commonly used multimedia tools. According to Lundberg (2008), Multimedia animations can improve a learner's capability to remember information. With images, sounds and actions, animations can interpret complicated abstract ideas for students. Chiou et al. (2013) have shown the MCM (Multidimensional Concept Maps) and MAMCM (Multimedia and a Multidimensional Concept Map) as an educating tool that can help students to comprehend complicated ideas, recognize misapprehensions, and positively influences student's contentment, motivation, and studying accomplishment. According to knowledge processing concept, MCM has one shortcoming that they only use the visual system. However, MAMCM consist of both the visual system and the auditory system (Chiou et al., 2013). According to Brom (2011), MAMCM increases the students' learning accomplishments and learning retention than MCM and MAMCMs get better students' learning fulfillment than MCM. Clark et al. (2013) suggested that several trails can now be treaded for the sake of learning such as learning through multimedia by playing games related to course areas, tools used for transcription and other ways through which it reinforces the motivation. 


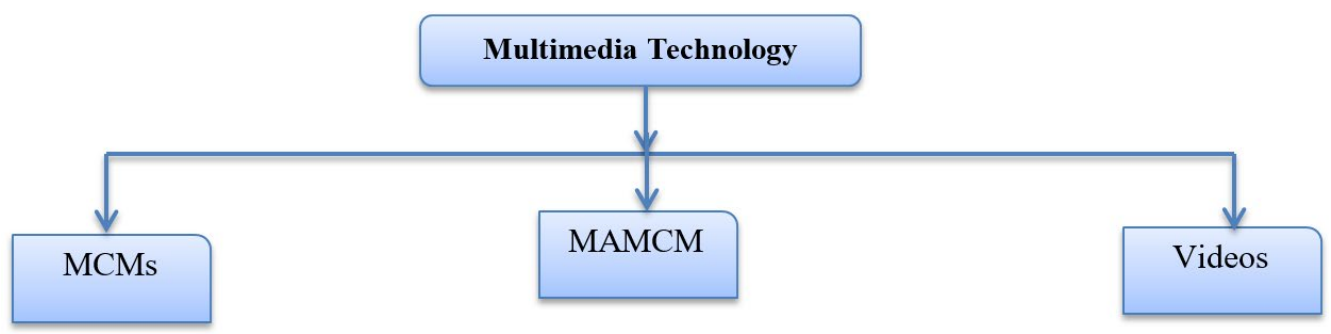

Figure 3. Use of Multimedia-based technologies in education

Table 3. Use of Multimedia-based technologies in education

\begin{tabular}{lccc}
\hline \multirow{2}{*}{ Reference } & \multicolumn{2}{c}{ Multimedia-Based Technology } \\
\cline { 2 - 4 } & Video & MAMCM & MCMs \\
\hline Brom, Preuss, and Klement (2011) & $\checkmark$ & $\checkmark$ & $\checkmark$ \\
\hline Lundberg, Castillo-Merino, and Dahmani (2008) & $\checkmark$ & X & $\checkmark$ \\
\hline Davies, and Cormican (2013) & $\checkmark$ & X & $\checkmark$ \\
\hline Knutas, Herala, Vanhala, and Ikonen (2016, June) & $\checkmark$ & $\checkmark$ & $\checkmark$ \\
\hline MacNeil, Latulipe, Long, and Yadav (2016) & $\checkmark$ & $\checkmark$ & $\checkmark$ \\
\hline Chiou, Tien, and Lee (2015) & $\checkmark$ & $\checkmark$ & $\checkmark$ \\
\hline Clark, and Luckin (2013) & $\checkmark$ & $\checkmark$ & $\checkmark$ \\
\hline Koehler, Greenhalgh, Rosenberg, and Keenan (2017) & X & $\checkmark$ & $\checkmark$ \\
\hline
\end{tabular}

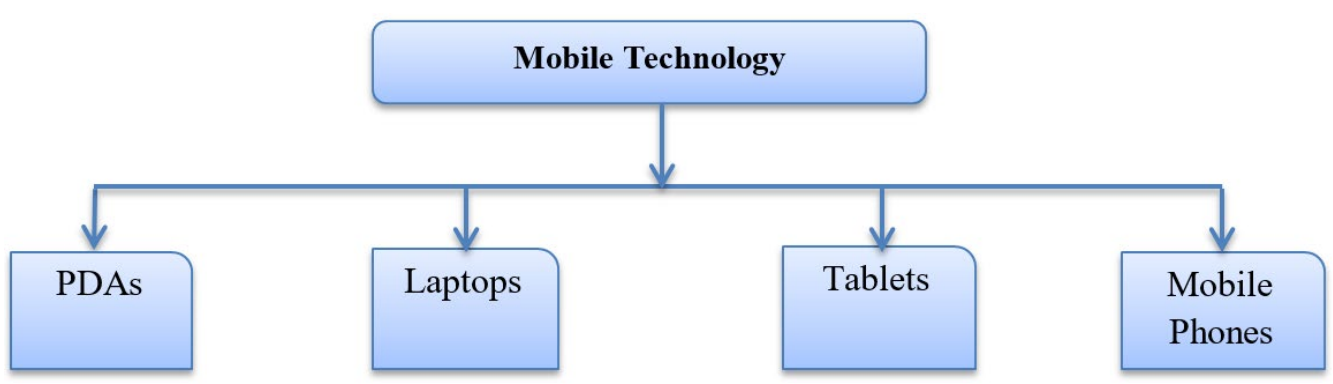

Figure 4. Education by using Mobile Devices

Knutas et al. (2016) stated that the importance and need for technology in education are absolutely evident. Moreover, the authors mentioned that the use of animation tools have improved understanding. MacNeil et al. (2016) asserted that it is palpable that the application of technological tools has influenced and impacted the motivation level of students. Maher (2015) have explored the different animation tools that have been created in recent decades to focus on learning computer science and to clarify the theoretical concepts and make them more understandable. Koehler et al. (2017) stated that most learners look at the use of video lectures in a positive way but quite a few learners do not watch all the available video contents. In addition, it is determined that the circumstances for creating video lessons on a bigger range must be properly examined.

\section{Mobile Technology as an Educational Resource}

In recent years, mobile technology has rapidly grown. Figure 4 shows the usage of mobile devices as an educational resource. Karsenti et al. (2013) stated that mobile technology provides easy usage, helps students to learn independently, motivates students to interact and make social connections, and helps them in quench their inquisitive thirst. According to Lovrencic et al. (2016), mobile-based technological advancement has led to most people to carry their own individual small computer systems that contain notable processing capability such as notebooks, PDAs (Personal Digital Assistance) personal computers, tablets, mobile phones, and e-book readers.

According to Montrieux et al. (2015), mobile technologies have excellent prospects for assisting advanced academic techniques. Mostly learners used their laptops mobile phones, PDAs to write, make demonstrations, browse the Internet, do preparation, or take tests. ChanLin et al. (2017) have assessed the overall efficiency of developing mobile technological innovation in education on learner's learning accomplishments. Cowan et al. (2013) elaborated that the growing usage of mobile technology has formed "pockets of educational potential" as learning through mobile technology can help shatter the barricades because of its reachability (i.e., anytime and anywhere). Sung et al. (2016) stated that mobile technology has the potential to keep the user directed towards 
Table 4. Use of mobile technology in education

\begin{tabular}{|c|c|c|c|c|}
\hline \multirow{2}{*}{ Reference } & \multicolumn{4}{|c|}{ Mobile Technology } \\
\hline & Laptops & PDA & Tablets & Mobile Phones \\
\hline Lovrenčić, and Čubrilo (2016) & $\checkmark$ & $\checkmark$ & $\checkmark$ & $\checkmark$ \\
\hline Montrieux, Vanderlinde, Schellens, and De Marez (2015) & $\checkmark$ & $\checkmark$ & $\checkmark$ & $\checkmark$ \\
\hline ChanLin (2017) & $\checkmark$ & $\checkmark$ & $\checkmark$ & $\checkmark$ \\
\hline Shuler (2009) & $\checkmark$ & $\mathrm{x}$ & $\checkmark$ & $\checkmark$ \\
\hline Bissell (2015) & $\mathrm{X}$ & $\checkmark$ & $\mathrm{X}$ & $\checkmark$ \\
\hline Cowan, and Butler (2013) & $\mathrm{X}$ & $\checkmark$ & $\mathrm{X}$ & $\checkmark$ \\
\hline Huang, Jeng, and Huang (2009) & $\mathrm{x}$ & $\checkmark$ & $\mathrm{x}$ & $\checkmark$ \\
\hline Karsenti, and Fievez (2013) & $\checkmark$ & $\checkmark$ & $\checkmark$ & $\checkmark$ \\
\hline Maher (2015) & $\checkmark$ & $\mathrm{X}$ & $\checkmark$ & $\mathrm{X}$ \\
\hline Kim, Hagashi, Carillo, Gonzales, Makany, Lee, and Garate (2011) & $\checkmark$ & $\mathrm{X}$ & $\checkmark$ & $\mathrm{X}$ \\
\hline Sung, Chang, and Liu (2016) & $\mathrm{X}$ & $\mathrm{X}$ & $\checkmark$ & $\mathrm{x}$ \\
\hline Kim, and Kim (2017) & $x$ & $x$ & $\checkmark$ & $\checkmark$ \\
\hline Ifenthaler, and Schweinbenz (2013) & $\mathrm{X}$ & $\checkmark$ & $\mathrm{X}$ & $\checkmark$ \\
\hline
\end{tabular}

\begin{tabular}{|l|l|l}
\hline Web MOOCs & \\
& & \\
\end{tabular}

active learning even if there are no educational resources present. It has been proved that mobile learning devices are highly influential especially for students who are lacking the school performance.

\section{Online Learning Tools Used in Education}

Teaching online courses, related to computer science can leave a significant impact on students. According to Musca et al. (2016), the various learning styles adopted in educational systems do not actually impact the way students communicate with their peers, teachers, or media but they do affect students' performance related to class participation and group activities. Online learning methods are diverse and hence can be used in various domains but at the same time, they come as a convenient tool that can be used pedagogically. Figure 5 shows the two most widely used online learning tools i.e., MOOCs and flipped classroom. Schreiber et al. (2017) have explained the Massive Open Online Course (MOOC) is a web-based class designed to support a large number of members. A key advantage of MOOCs over traditional classroom-based studying is their accessibility.

Jonsson et al. (2015) describe that the fundamental principle of flipped classroom teaching is to provide the contents outside of the class. According to Herala, et al. (2015), inverted or a flipped classroom educating technique has two main components: provide educational material outside of the classroom (typically online) and shift effective studying into the classroom. According to Dobrzański et al. (2008) these two elements start up four educational style challenges: 1) how to framework the student's basic work; 2) how to provide educational material out-of-class; 3 ) how to develop effective studying activities to use in-class to scaffolding studying, identify misunderstandings and allow students to practice critical skills; and finally, 4) how to framework student interaction to best make use of social studying and peer instruction. 


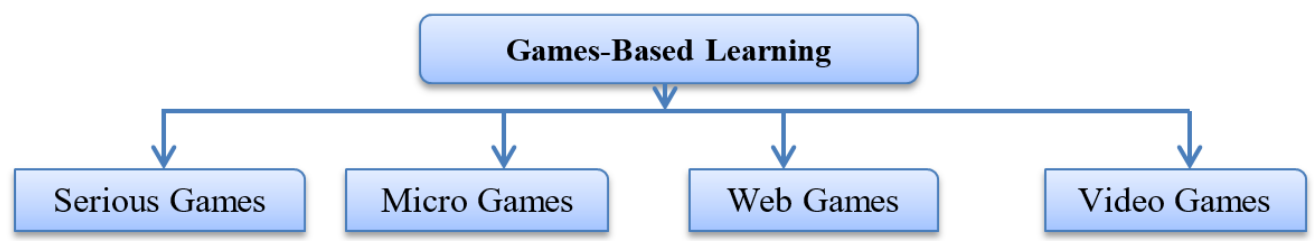

Figure 6. Use of Games-based approach in teaching

Table 6. Games-based learning approaches in teaching and learning

\begin{tabular}{|c|c|c|c|c|}
\hline \multirow[b]{2}{*}{ Reference } & \multicolumn{4}{|c|}{ Games-based Learning } \\
\hline & VGs & $\begin{array}{c}\text { Web } \\
\text { Games }\end{array}$ & $\begin{array}{l}\text { Serious } \\
\text { Games }\end{array}$ & $\begin{array}{l}\text { Micro } \\
\text { Games }\end{array}$ \\
\hline Sung, Chang, and Liu (2016) & $\checkmark$ & $\checkmark$ & $\checkmark$ & $\checkmark$ \\
\hline Wang, DeMaria Goldberg, and Katz (2016) & $\checkmark$ & $\checkmark$ & $\mathrm{x}$ & $\checkmark$ \\
\hline Chen, Yang, Huang, and Fu (2017) & $\checkmark$ & $\checkmark$ & $\checkmark$ & $\checkmark$ \\
\hline Lavelle, Stimpson, and Brill (2015) & $\checkmark$ & $\checkmark$ & $\checkmark$ & $\checkmark$ \\
\hline Watson, Mong, and Harris (2011) & $\checkmark$ & $\checkmark$ & $\checkmark$ & $\checkmark$ \\
\hline Alves, Schmidt, Carthcat, and Hostins (2015) & $\checkmark$ & $\checkmark$ & $\mathrm{X}$ & $\mathrm{X}$ \\
\hline Annetta, Minogue, Holmes, and Cheng (2009) & $\mathrm{x}$ & $\mathrm{X}$ & $\checkmark$ & $\mathrm{X}$ \\
\hline Beale, Kato, Marin-Bowling, Guthrie, and Cole (2007) & $\checkmark$ & $\mathrm{X}$ & $\checkmark$ & $\mathrm{X}$ \\
\hline Boot, Kramer, Simons, Fabiani, and Gratton (2008) & $\checkmark$ & $\mathrm{x}$ & $\mathrm{x}$ & $\checkmark$ \\
\hline Hainey, Connolly, Stansfield, and Boyle (2011) & $\mathrm{x}$ & $\mathrm{x}$ & $\checkmark$ & $\mathrm{X}$ \\
\hline Kebritchi, Hirumi, and Bai (2010) & $\mathrm{X}$ & $\mathrm{X}$ & $\checkmark$ & $\mathrm{X}$ \\
\hline Knight, Carley, Tregunna, Jarvis, Smithies, de Freitas, and Mackway-Jones (2010) & $\mathrm{X}$ & $\mathrm{X}$ & $\checkmark$ & $\mathrm{X}$ \\
\hline Lorant-Royer, Spiess, Goncalves, and Lieury (2008) & $\checkmark$ & $x$ & $x$ & $x$ \\
\hline Tanes, and Cemalcilar (2010) & $\checkmark$ & $\mathrm{X}$ & $\mathrm{X}$ & $\mathrm{X}$ \\
\hline Wrzesien, and Raya (2010) & $\mathrm{x}$ & $x$ & $\checkmark$ & $x$ \\
\hline
\end{tabular}

\section{Games-based Learning}

Different games play a crucial role in the learning growth of students by allowing them to play and experiment with these. Lately, there has been an increase in several types of games including video games, web games, etc. Jonsson et al. (2015) argued that games can help students in learning new concepts related to chemistry, geometry, programming, etc. Figure 6 shows different games-based tools such as serious games, video games, microgames, and web games used for learning and teaching purpose. According to Schreiber et al. (2017), information learned in the expository formal training can be used as content for self-learning associated with text content on different algorithms. The game should not be used as an unaccompanied activity. The games' purpose is to strengthen and incorporate part of the information learned in the expository session. Lavelle et al. (2015) have revealed that members who played the digital game prepared with animated, cartoon-style, interactive, and entertaining features obtained imperative higher than the lower-complexity digital game team as well as the customary paper-and-pencil team on the training outcome assessments. The members who performed digital game showed better learning outcomes. Watson et al. (2011) mentioned that the appropriate game's activities can enhance a student's sense of self-confidence and even enhance socializing abilities, management abilities, and team development. The past few years have seen the development of serious games (SGs) that are surging the academic games industry. According to Wang et al. (2016), the vibrant characters of games and background designs and the collaborative effects may have the ability to mend students' short-term memorization of the information retention capability. According to Alves et al. (2015), video games are used in skill development and concept studying, in-class lab activities supporting open-ended tasks and enhance technical/professional studying. Brom et al. (2011) have evaluated the potency of various serious games and video games on students.

According to Chen et al. (2017), the use of serious games in education is a developing area that requires ongoing evaluation and the organization of the best methodologies. Serious gaming is a developing training system for education that provides a range of learning goals and expertise via numerous game styles. Fonseca et al. (2014) stated that the evaluation of serious games as training tools is essential. Sung et al. (2016) stated that it is necessary to perform experimental research evaluating the influence on studying of non-coaching; pencil-and-paper training, serious games, and video games-based training. To evaluate the long-term impact of teaching using SGs it is necessary to perform longitudinal research. Sung et al. (2016) have suggested that we should avoid becoming overzealous about the serious games that are currently surging the market until their efficiency in studying has 


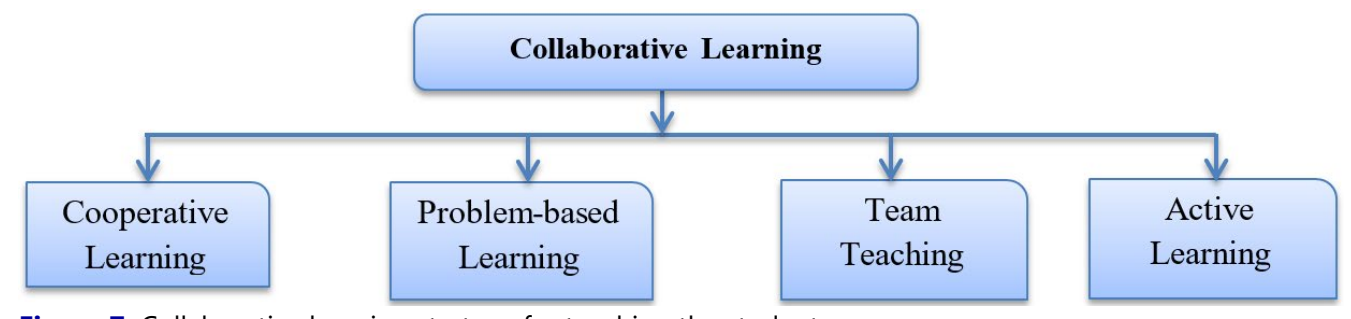

Figure 7. Collaborative learning strategy for teaching the students

Table 7. Use of collaborative learning strategy in teaching and learning

\begin{tabular}{lcccc}
\hline \multirow{2}{*}{ Reference } & \multicolumn{3}{c}{ Collaborative Learning } \\
\cline { 2 - 5 } & $\begin{array}{c}\text { Cooperative } \\
\text { Learning }\end{array}$ & $\begin{array}{c}\text { Problem-Based } \\
\text { Learning }\end{array}$ & $\begin{array}{c}\text { Team } \\
\text { Teaching }\end{array}$ & $\begin{array}{c}\text { Active } \\
\text { Learning }\end{array}$ \\
\hline Bishop, and Verleger (2013) & $\checkmark$ & $\mathrm{X}$ & $\checkmark$ & X \\
\hline Roehl, Reddy, and Shannon (2013) & $\checkmark$ & $\checkmark$ & $\mathrm{X}$ & $\checkmark$ \\
\hline Vogel, Vogel, Cannon-Bowers, Bowers, Muse, and Wright (2006) & $\checkmark$ & $\checkmark$ & $\mathrm{X}$ & $\mathrm{X}$ \\
\hline Nørmark (2016) & $\checkmark$ & $\checkmark$ & $\mathrm{X}$ & $\checkmark$ \\
\hline Zurita, Nussbaum, and Salinas (2005) & $\checkmark$ & $\mathrm{X}$ & $\mathrm{X}$ & $\checkmark$ \\
\hline Huang, Jeng, and Huang (2009) & $\checkmark$ & $\mathrm{X}$ & $\mathrm{X}$ & $\checkmark$ \\
\hline
\end{tabular}

been demonstrated scientifically. Nevertheless, this evaluation also needs to emphasize the advantageous factors for the creation of serious games, which can be proved to be the academic tool of the future.

\section{COLLABORATIVE LEARNING STRATEGY}

Liaw and Huang et al. (2009) defined collaborative learning as students and teacher working and learning together in the form of various group activities. This concept takes its basis from the fact that learning is more effective in environments that are socially conducive. Figure 7 shows collaborative learning techniques. Nørmark (2016) stated that these kinds of activities usually revolve around the following four fundamentals: the student should be at the center where every required material is accessible to him, there should be an emphasis on communication, group work should be prioritized, and problem-solving ability should be developed.

Roehl Reddy and Shannon (2013) have mentioned the three key parts of collaborative learning:

1. Learners work in groups toward the achievement of some extremely ordinate objectives.

2. Work is separated from associates, such that each person takes liability for a different sub-goal.

3. Individual efforts are combined into an amalgamated product to ensure that the objective is achieved.

Lesco et al. (2017) described that the teachers should occupy themselves in group learning by joining different communities online, where they would get to share and exchange innovative ideas. Technology can contribute a great deal to the educational sphere by using digital tools and can enable the students and teachers to engage in work more effectively. Many universities are adopting this approach by integrating digital features and hence promoting active learning. According to Boud, Cohen, and Sampson (2014) in team teaching-learning or peer learning, students can get an opportunity to receive the feedback from the other fellow students in the group regarding their knowledge and understanding. Therefore, learners can learn from each other and create an environment where they can share knowledge. Discussing different experiences improves a group's creative skills and problem-solving ability. Furthermore, seeing that others' opinions can enhance their thinking and can motivate learners to listen and accept other alternative opinions as well. Vogel et al. (2006) stated that active learning is an educational method that involves learners in the training process. Bishop et al. (2013) have mentioned the following features of problem-based studying: Student-Centered learning, learning in small groups where instructors are the facilitator and new information is obtained through self-directed studying. According to Bishop et al. (2013), the objective of problem-based studying includes helping students develop versatile information, efficient problemsolving abilities, self-directed studying abilities, efficient cooperation abilities, and implicit motivation.

\section{ALGORITHMS BASED LEARNING}

According to Sorva et al. (2013), many techniques produce computer animation straight from the code, such as JAVAVIS. The use of computer animation improves the educational requirements in the information technology profession. More significantly, to take advantage of using computer animation for imagining methods is to fix the following issues: First, in order to entice learners to use any computer animation program, the designer should 


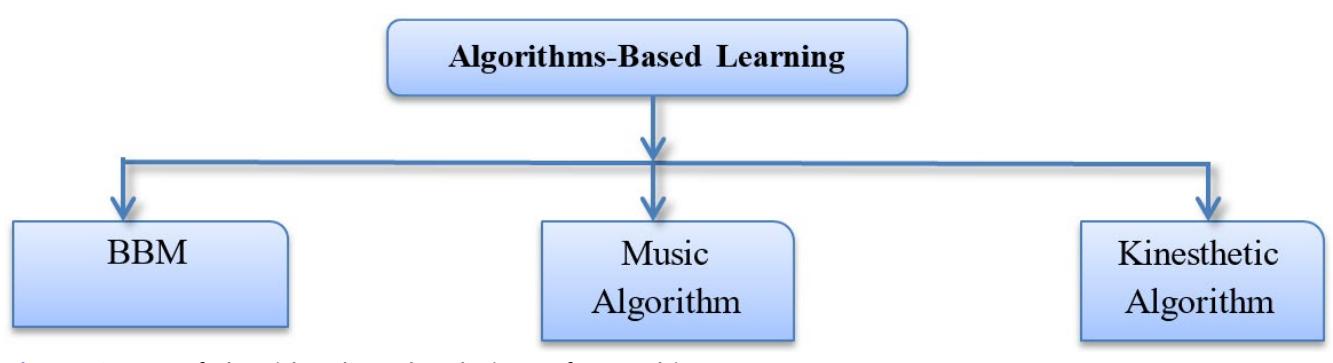

Figure 8. Use of algorithm-based techniques for teaching

Table 8. Algorithmic-based techniques for teaching

\begin{tabular}{lccc}
\hline Reference & BBM & $\begin{array}{c}\text { Music Algorithm Based } \\
\text { Approach }\end{array}$ & $\begin{array}{c}\text { Kinesthetic Learning } \\
\text { Algorithm }\end{array}$ \\
\hline Fatimah, Norah, and Young (2017) & X & X & $\checkmark$ \\
\hline Brom, Preuss, and Klement (2011) & $\checkmark$ & $X$ & $X$ \\
\hline Kikot, Costa, Magalhães, and Fernandes (2013) & X & $\checkmark$ & $X$ \\
\hline
\end{tabular}

reduce the cost of using the programs or ensure it as a free tool. Second, learners should have the capability to stop computer animation if they get puzzled. This mechanism assists them to review the learning parts and to better understand these.

The algorithm-based techniques are shown in Figure 8. Fatimah et al. (2017) have developed alternative modules for educating different scheduling algorithms, which are Round-Robin (RR), Shortest-Job-First (SJF), FirstCome-First-Serve (FCFS), and Priority based mechanisms. The algorithm-based techniques mostly contain two modules: KLAs and web games. KLAs are the most common methods employed to have an active and collaborative learning mechanism. The web activities enable users to connect to the performance of methods via dragging and dropping activities in the playing method or following the computer-based animation to see the simulated algorithm. In addition to web games, KLAs component has numerous advantages; students learn through physical activity and communications during the lecture instead of staying for quite a long time and only paying attention to the teacher's lecture.

The Black Box Method (BBM) in electrical technological innovation was first used in 1956 by Ashby. According to Brom et al. (2011), the student is given an enclosed box that has a terminal for input to which it will provide any current, bumps, or other disruptions; and a terminal for the result or output so that he may observe the outcome. The BBM mechanism is a substantial program (e.g., phenomenon, object, procedure), framework and factor behavior, about which the viewer has no details, but has the choice of affecting the whole program via its details and notice its responses via the results. The viewer impacts the black box via its feedback and gets detail from the outcome. Similarly, the viewer and the BBM make a program with the feedback option.

\section{DISCUSSION}

The purpose of this study is to scrutinize the technological tools and teaching approaches to analyze the overall efficiency of these technological tools employed for teaching computer science. In this survey, we review the effectiveness of including technological tools for teaching computer science such as, simulations and audio-visual demonstrations of content (videos and video clips), multimedia, computer-based instructions, kinesthetic learning algorithms, video games, problem-based learning, web games, Web MOOCS tools in comparison to a traditional lecture-based method.

Implementing the use of technological tools in teaching increases student motivation, social interactions, positive outcomes, and it enhances students learning capability and engagement. Technology is a source to unlock the key to learning. According to Keser, Huseyin, \& Ozdamli, (2011) through the use of technological tools students are able to keep in touch with information for instance, in classroom groups, online, and in virtual environments. Students collaboration have also been increased with the use of these technological tools as students work together and cooperate with each other to create projects, make assignments, do the lab practical, etc. Baytak, Tarman, and Ayas (2011) in research found that most students believe that integrating technology into the curriculum plays an important role in the improvement of their learning capabilities. Integration of technology in education is also helpful for students with special learning. Weaver, et al. (2015) stated that the integration of technology in education has increased the motivation level of students and the engagement in the learning process. The collaboration has been increased among students. According to Prensky (2008) generally, television, computer, and internet are included in ICT and when they are used appropriately can boost, strengthen, and raise the standard of education. In teaching computer science, the contribution of ICT is also very important as it provides new tools which include 
worksheets, databases, statistical, and graphical programs. By employing ICT in educational systems, active learning can be perpetuated and ICT can promote creativity and imagination in students. Our study explores that the usage of ICT can greatly promote creativity and imagination-based learning in students. Ultimately, the foremost step that should be observed in the application of ICT is that it should be influential and operative in a way that teachers and students would get the best from it. It has been proved that the students who were taught by the implementation of technological tools were more likely to be cognizant and had the ability to critically and cognitively analyze the problems when compared with the students who were taught in a traditional manner.

Another technological approach the flipped classroom has gotten to everybody's hearing by now. In this approach, the students can learn through by watching the video lectures as their homework and then they can discuss it with the teacher in the classroom. It has led to an extremely better performance of students, with a significant increase in grades. By using this method students learn things in a better way and it also reduces the learning effort and time (Arfstrom et al., 2013)

There is a significant impetus towards presenting online courses for learning such as MOOCs i.e., massive open online courses and flipped classrooms but their efficiency pertinent to cost is not much known yet. Taking online computer science courses might be a bit challenging not just for the students but also for the teachers. Research has shown that a teacher should investigate the learning styles of his/her students prior to providing them with an online course because learning styles affect students' understanding. Interactive learning and communication are the factors that help in making up the environment of an online course. Moreover, online computer science courses must provide solid interactive and communicative prospects to the students so that they would be able to tackle complex problems and deal with peers and teachers in an efficient way. In order to maintain the interactive and collaborative atmosphere of the course, instructors are required to present all the necessary information. Instructors and the creators of the course need to be cognizant of the educational requirements of the students if they want to produce happy and learned students.

The evaluation of the games as gears used for training is extremely necessary but considering its diversity, is still very much in need of improvement. A sheer lack of experiential research can be observed when it comes to inspecting the impact of serious games and video games. It is essential to hold a great many empirical studies before making a claim that games produce an effective result.

Mobile technology has become an important and undeniable influence over the students because of the ideas of motivation and achievement that it gives to the students. Through the use of mobile technology, the classroom can be taken anywhere. With all the knowledge and sources included and deliverable when needed in a cellular phone, learners can learn at home. Neo et al. (2009) concluded that mobile technology also promotes better collaboration and a strong foundation in group work between students. The mobile phone saves time and provides information anytime or anywhere without any hurdle.

Multimedia has to get over the limitations of space and time and can be used as a device for educating students. Multimedia provides a technological advancement-based constructivist studying atmosphere where the learners are able to fix a problem by means of active participation, cooperation, and self-exploration. Animated graphics, simulations audio and video incorporated in an organized manner accomplish the process of learning new knowledge much more efficiently. According to Malik, and Agarwal (2012) the nature of multimedia is interactive which provides the room to improve the traditional "chalk-and-talk" way of teaching and learning. It assists both the students and teachers to work together. Moreover, it improves and motivates group study as well as personal innovation and creativeness.

This research detected a positive impact on technology use in computer science education. However, investigation of efficiency by these parameters indicated that different parameters are valuable under some particular circumstances. We don't anticipate technology commutation impassioned instructors teaching their learners. We just see it as an important device to help the methodology of education and get ready the learners for the future. From the research we have check out, instructors got to use a lot of technological tools inside the space. This research shows that the use of technology, video games, computer-aided instructions, and mobile devices are more effective in teaching computer science. Consequently, these methodologies are more effective when used as a supplement to traditional instruction rather than as a substitute. Therefore, instead of substituting the entire class time with these techniques, the use of such technology in conjunction with other educating strategies could be greater for the students. The idea of mixing a custom-blend of these techniques into the everyday classic teaching method is one that is practical and comfortable. It is not overwhelming to teachers as it does not demand them to fully change the ways of teaching that they have followed and believed in over the years.

The goal of this study was to highlight that the use of technological tools in academics comes with a risk for the institution, although these tools have a lot of potentials however they are not without challenges. Technological tools and traditional tools can both not foster motivation and will to learn in students. What makes a difference is the ways in which these methods are utilized by students and teachers alike. The technological tools have an 
important role in the academic environment only if they nurture the mission of education which is to socialize, provide instruction and education.

\section{CONCLUSIONS}

It can be concluded that educational technology is the field of education that is still in its evolutionary stages. Nevertheless, technology is in a much rapid evolutionary stage relative to education. It would be intriguing to behold the way things are going to pick up in the upcoming years when the consequences of global proliferation and digital and networking technology would develop. Furthermore, the restrictions of technological tools faced by educators and instructors would be worth studying. Empirical research is also essential to get a further look into the effects of technology.

We explored the literature available about the influence of technological tools and their consequences in the field of education. The paper has been concluded after reviewing the necessity and influence of employing technological tools in pedagogical contexts. To incorporate technology, educators and teachers must implement the right technological tools to make the environment more innovative for the students.

\section{REFERENCES}

Altbach, P. G., Reisberg, L., \& Rumbley, L. E. (2009). Trends in global higher education: Tracking an academic revolution. The Netherlands: Sense Publishers.

Alves, A. G., Schmidt, A. E. F., Carthcat, K. D., \& Hostins, R. C. (2015). Exploring technological innovation towards inclusive education: Building digital games-An interdisciplinary challenge. Procedia-Social and Behavioral Sciences, 174, 3081-3086. https:/ / doi.org/10.1016/j.sbspro.2015.01.1043

Amirault, R. J. (2015). Technology transience and the challenges it poses to higher education. Quarterly Review of Distance Education, 16(2), 1.

Amutha, S. (2016). Impact of e-content integration in science on the learning of students at tertiary level. International Journal of Information and Education Technology, 6(8), 643. https:/ / doi.org/10.7763/IJIET.2016.V6.766

Annetta, L. A., Minogue, J., Holmes, S. Y., \& Cheng, M. T. (2009). Investigating the impact of video games on high school students' engagement and learning about genetics. Computers $\mathcal{E}$ Education, 53(1), 74-85. https:/ / doi.org/10.1016/j.compedu.2008.12.020

Arfstrom, K. M., \& Network, P. D. F. L. (2013). A white PAPer BAsed on the LiterAture review titled A Review of flipped learning. Noora Hamdan and Patrick McKnight, Flipped Learning Network.

Bakar, R., \& Mohamed, S. (2008). Teaching using information and communication technology: Do trainee teachers have the confidence?. International Journal of Education and Development using ICT, 4(1), 5-12. https://doi.org/10.3844/jssp.2008.62.67

Baytak, A., Tarman, B., \& Ayas, C. (2011). Experiencing technology integration in education: children's perceptions. International Electronic Journal of Elementary Education, 3(2), 139-151.

Beale, I. L., Kato, P. M., Marin-Bowling, V. M., Guthrie, N., \& Cole, S. W. (2007). Improvement in cancer-related knowledge following use of a psychoeducational video game for adolescents and young adults with cancer. Journal of Adolescent Health, 41(3), 263-270 https:/ / doi.org/10.1016/j.jadohealth.2007.04.006

Beyth-Marom, R., Saporta, K., \& Caspi, A. (2005). Synchronous vs. asynchronous tutorials: Factors affecting students' preferences and choices. Journal of Research on Technology in Education, 37(3), 245-262. https://doi.org/10.1080/15391523.2005.10782436

Bishop, J. L., \& Verleger, M. A. (2013, June). The flipped classroom: A survey of the research. In ASEE national conference proceedings, Atlanta, GA (Vol. 30, No. 9, pp. 1-18).

Bissell, J. (2015, March). Utilization of mobile learning technology to enhance curriculum. In Society for Information Technology \& Teacher Education International Conference (pp. 1582-1587). Association for the Advancement of Computing in Education (AACE).

Boot, W. R., Kramer, A. F., Simons, D. J., Fabiani, M., \& Gratton, G. (2008). The effects of video game playing on attention, memory, and executive control. Acta psychologica, 129(3), 387-398. https:/ / doi.org/10.1016/j.actpsy.2008.09.005

Boud, D., Cohen, R., \& Sampson, J. (2014). Peer learning in higher education: Learning from and with each other. Routledge.

Butler, A. C., Marsh, E. J., Slavinsky, J. P., \& Baraniuk, R. G. (2014). Integrating cognitive science and technology improves learning in a STEM classroom. Educational Psychology Review, 26(2), 331-340. https:/ / doi.org/10.1007/s10648-014-9256-4 
ChanLin, L. J. (2017). Analysis of Teachers' Tablet Teaching Adoption Process. Educational Sciences: Theory $\mathcal{E}$ Practice, 17(6). https:// doi.org/10.12738/estp.2017.6.0436

Chen, F. H., Looi, C. K., \& Chen, W. (2009). Integrating technology in the classroom: a visual conceptualization of teachers' knowledge, goals and beliefs. Journal of Computer Assisted Learning, 25(5), 470-488. https:// doi.org/10.1111/j.1365-2729.2009.00323.x

Chen, S. W., Yang, C. H., Huang, K. S., \& Fu, S. L. (2017). Digital games for learning energy conservation: A study of impacts on motivation, attention, and learning outcomes. Innovations in Education and Teaching International, 1-11. https:/ / doi.org/10.1080/14703297.2017.1348960

Chiou, C. C., Tien, L. C., \& Lee, L. T. (2015). Effects on learning of multimedia animation combined with multidimensional concept maps. Computers $\mathcal{E}$ Education, 80, 211-223. https:// doi.org/10.1016/j.compedu.2014.09.002

Clark, W., \& Luckin, R. (2013). iPads in the Classroom. What The Research Says.

Cowan, P., \& Butler, R. (2013). Using activity theory to problematize the role of the teacher during mobile learning. SAGE Open, 3(4), 2158244013516155. https:/ / doi.org/10.1177/2158244013516155

Davies, W., \& Cormican, K. (2013). An analysis of the use of multimedia technology in computer-aided design training: Towards effective design goals. Procedia Technology, 9, 200-208. https:// doi.org/10.1016/j.protcy.2013.12.022

Davis, F. D. (1989). Perceived usefulness, perceived ease of use, and user acceptance of information technology. MIS quarterly, 319-340. https:/ / doi.org/10.2307/249008

Delialioglu, O., \& Yildirim, Z. (2007). Students' perceptions of effective dimensions of interactive learning in a blended learning environment. Journal of Educational Technology \& Society, 10(2).

Dobrzański, L. A., \& Brom, F. (2008). E-learning on the example of materials science. Journal of Achievements in Materials and Manufacturing Engineering, 29(1), 99-102.

Fatimah, A. K., Norah, A. O., \& Young, G. (2017). Two Alternative Modules for Teaching Scheduling Algorithms in Computer Science Using Web Games and Kinesthetic Learning Activities. Paper Presented at the Int'l Conf. Frontiers in Education: CS and CE, FECS 2017.

Figueiredo, A. D. (2006). Context and learning: A philosophical framework. In Managing learning in virtual settings: The role of context (pp. 1-23). IGI Global. https:/ / doi.org/10.4018/978-1-59140-488-0.ch001

Finger, G., \& Trinidad, S. (2002). ICTs for learning: An overview of systemic initiatives in the Australian states and territories. Australian Educational Computing, 17(2), 3-14.

Fleming, N. D. (2001). Teaching and learning styles: VARK strategies. IGI Global.

Ghavifekr, S., \& Rosdy, W. A. W. (2015). Teaching and learning with technology: Effectiveness of ICT integration in schools. International Journal of Research in Education and Science, 1(2), 175-191. https://doi.org/10.21890/ijres.23596

Gulatee, Y., \& Combes, B. (2006). Identifying the challenges in teaching computer science topics online.

Gulbahar, Y., \& Guven, I. (2008). A survey on ICT usage and the perceptions of social studies teachers in Turkey. Journal of Educational Technology E Society, 11(3).

Hainey, T., Connolly, T. M., Stansfield, M., \& Boyle, E. A. (2011). Evaluation of a game to teach requirements collection and analysis in software engineering at tertiary education level. Computers $\mathcal{E}$ Education, 56(1), 2135. https:/ / doi.org/10.1016/j.compedu.2010.09.008

Herala, A., Vanhala, E., \& Nikula, U. (2015, November). Object-oriented programming course revisited. In Proceedings of the 15th Koli Calling Conference on Computing Education Research (pp. 23-32). ACM. https:/ / doi.org/10.1145/2828959.2828974

Huang, Y. M., Jeng, Y. L., \& Huang, T. C. (2009). An educational mobile blogging system for supporting collaborative learning. Journal of Educational Technology \& Society, 12(2).

Hussain, A. J., Morgan, S., \& Al-Jumeily, D. (2011, December). How Does ICT Affect Teachings and Learning within School Education. In Developments in E-systems Engineering (DeSE), 2011 (pp. 250-254). IEEE. https:/ / doi.org/10.1109/DeSE.2011.50

Ifenthaler, D., \& Schweinbenz, V. (2013). The acceptance of Tablet-PCs in classroom instruction: The teachers' perspectives. Computers in human behavior, 29(3), 525-534. https:/ / doi.org/10.1016/j.chb.2012.11.004

Jonsson, H. (2015, October). Using flipped classroom, peer discussion, and just-in-time teaching to increase learning in a programming course. In Frontiers in Education Conference (FIE), 2015 IEEE (pp. 1-9). IEEE. https:/ / doi.org/10.1109/FIE.2015.7344221 
Karsenti, T., \& Fievez, A. (2013). The iPad in education: uses, benefits, and challenges. A survey of, 6057.

Kearney, M., \& Maher, D. (2013). Mobile learning in maths teacher education: Using iPads to support pre-service teachers' professional development. Australian Educational Computing, 27(3), 76-84.

Kebritchi, M., Hirumi, A., \& Bai, H. (2010). The effects of modern mathematics computer games on mathematics achievement and class motivation. Computers $\mathcal{E}$ education, 55(2), 427-443. https://doi.org/10.1016/j.compedu.2010.02.007

Keser, H., Uzunboylu, H., \& Ozdamli, F. (2011). World Journal on Educational Technology. Technology, 3(2), $103-$ 119.

Kikot, T., Costa, G., Magalhães, R., \& Fernandes, S. (2013). Simulation games as tools for integrative dynamic learning: The case of the management course at the University of Algarve. Procedia Technology, 9, 11-21. https:// doi.org/10.1016/j.protcy.2013.12.002

Kim, H. J., \& Kim, H. (2017). Investigating teachers' pedagogical experiences with tablet integration in Korean rural schools. The Asia-Pacific Education Researcher, 26(1-2), 107-116. https:/ / doi.org/10.1007/s40299-017-0331-8

Kim, P., Hagashi, T., Carillo, L., Gonzales, I., Makany, T., Lee, B., \& Garate, A. (2011). Socioeconomic strata, mobile technology, and education: A comparative analysis. Educational Technology Research and Development, 59(4), 465-486. https:/ / doi.org/10.1007/s11423-010-9172-3

Kirriemuir, J., \& McFarlane, A. (2004). Literature review in games and learning (Technical Report).

Knight, J. F., Carley, S., Tregunna, B., Jarvis, S., Smithies, R., de Freitas, S., ... Mackway-Jones, K. (2010). Serious gaming technology in major incident triage training: a pragmatic controlled trial. Resuscitation, 81(9), 11751179. https:/ / doi.org/10.1016/j.resuscitation.2010.03.042

Knutas, A., Herala, A., Vanhala, E., \& Ikonen, J. (2016, June). The Flipped Classroom Method: Lessons Learned from Flipping Two Programming Courses. In Proceedings of the 17th International Conference on Computer Systems and Technologies 2016 (pp. 423-430). ACM. https:/ / doi.org/10.1145/2983468.2983524

Koehler, M. J., Mishra, P., Kereluik, K., Shin, T. S., \& Graham, C. R. (2014). The technological pedagogical content knowledge framework. In Handbook of research on educational communications and technology (pp. 101-111). Springer, New York, NY. https:/ / doi.org/10.1007/978-1-4614-3185-5_9

Koehler, M., Greenhalgh, S., Rosenberg, J., \& Keenan, S. (2017). What the tech is going on with teachers' digital teaching portfolios? Using the TPACK framework to analyze teachers' technological understanding. Journal of Technology and Teacher Education, 25(1), 31-59.

Koh, J. H. L., Chai, C. S., Benjamin, W., \& Hong, H. Y. (2015). Technological Pedagogical Content Knowledge (TPACK) and design thinking: A framework to support ICT lesson design for 21st century learning. The Asia-Pacific Education Researcher, 24(3), 535-543. https:/ / doi.org/10.1007/s40299-015-0237-2

Kozma, R. B. (2005). National policies that connect ICT-based education reform to economic and social development. Human Technology: An interdisciplinary journal on humans in ICT environments. https://doi.org/10.17011/ht/urn.2005355

Kumbargoudar, P. (2013). Digital divide in India: Problems and prospects to bridge the divide.

Kurt, S. (2010). Technology use in elementary education in Turkey: A case study. New Horizons in Education, 58(1), 65-76.

Laferrière, T., Hamel, C., \& Searson, M. (2013). Barriers to successful implementation of technology integration in educational settings: A case study. Journal of Computer Assisted Learning, 29(5), 463-473. https:// doi.org/10.1111/jcal.12034

Lavelle, J. P., Stimpson, M. T., \& Brill, E. D. (2015). Evolution of a flipped engineering economy course. Age, $26,1$. https://doi.org/10.18260/p.24038

Liao, Y. C., Liao, C. W., Chen, C. H., \& Liao, Y. H. (2016). A study on learning effects of integrating information technology into electronics curriculum teaching. International Journal of Information and Education Technology, 6(11), 831. https:/ / doi.org/10.7763/IJIET.2016.V6.801

Liaw, S. S., \& Huang, H. M. (2016). Investigating learner attitudes toward e-books as learning tools: based on the activity theory approach. Interactive Learning Environments, 24(3), 625-643. https:/ / doi.org/10.1080/10494820.2014.915416

Lorant-Royer, S., Spiess, V., Goncalves, J., \& Lieury, A. (2008). Programmes d'entraînement cérébral et performances cognitives: efficacité, motivation... ou «marketing»? De la Gym-Cerveau au programme du Dr Kawashima... Bulletin de psychologie, (6), 531-549. https:/ / doi.org/10.3917/bupsy.498.0531 
Losco, C. D., Grant, W. D., Armson, A., Meyer, A. J., \& Walker, B. F. (2017). Effective methods of teaching and learning in anatomy as a basic science: A BEME systematic review: BEME guide no. 44. Medical teacher, 39(3), 234-243. https:/ / doi.org/10.1080/0142159X.2016.1271944

Lovrenčić, S., \& Čubrilo, M. (2016, January). Overview of Online Teaching Resources for Logic Programming. In The Seventh International Conference on eLearning (eLearning-2016 Conference).

MacNeil, S., Latulipe, C., Long, B., \& Yadav, A. (2016, February). Exploring lightweight teams in a distributed learning environment. In Proceedings of the 47th ACM Technical Symposium on Computing Science Education (pp. 193-198). ACM. https:// doi.org/10.1145/2839509.2844577

Maher, D. (2015). Connecting Classroom and Museum Learning with Mobile Devices. Journal of Museum Education, 40(3), 257-267. https:// doi.org/10.1179/1059865015Z.000000000102

Malek, N., Hall, J. C., \& Hodges, C. (2014). A review and analysis of the effectiveness of alternative teaching methods on student learning in economics. Perspectives on Economic Education Research, 9(1), 75-85.

Malik, S., \& Agarwal, A. (2012). Use of multimedia as a new educational technology tool-A study. International Journal of Information and Education Technology, 2(5), 468. https:/ / doi.org/10.7763/IJIET.2012.V2.181

Marcy, V. (n.d.). Introduction to VARK. VARK. [Online]. Retrieved on 05 February 2017 from http://varklearn.com/introduction-to-vark/

Mason, G. S., Shuman, T. R., \& Cook, K. E. (2013). Comparing the effectiveness of an inverted classroom to a traditional classroom in an upper-division engineering course. IEEE Transactions on Education, 56(4), 430435. https:/ / doi.org/10.1109/TE.2013.2249066

Melhuish, K., \& Falloon, G. (2010). Looking to the future: M-learning with the iPad. Computers in New Zealand Schools, 22(3), 1-16.

Montrieux, H., Vanderlinde, R., Schellens, T., \& De Marez, L. (2015). Teaching and learning with mobile technology: A qualitative explorative study about the introduction of tablet devices in secondary education. PloS one, 10(12), e0144008. https:/ / doi.org/10.1371/journal.pone.0144008

Musca, G., Mihalache, A., \& Musca, E. (2016, November). E-learning implementation in the superior technical educational system. In IOP Conference Series: Materials Science and Engineering (Vol. 161, No. 1, p. 012110). IOP Publishing. https://doi.org/10.1088/1757-899X/161/1/012110

Neo, M., \& Neo, T. K. (2009). Engaging students in multimedia-mediated Constructivist learning-Students' perceptions. Journal of Educational Technology \& Society, 12(2), 254.

Nørmark, K. (2016). The ongoing Digitalization of an Introductory Programming Course. In International Conference on e-Learning (Vol. 16, p. 67).

Olofson, M. W., Swallow, M. J., \& Neumann, M. D. (2016). TPACKing: A constructivist framing of TPACK to analyze teachers' construction of knowledge. Computers $\mathcal{E}$ Education, 95, 188-201. https:/ / doi.org/10.1016/j.compedu.2015.12.010

Prensky, M. (2008). The role of technology. Educational Technology, 48(6).

Rahmatian, R., \& Zarekar, F. (2016). Inductive/Deductive Learning by Considering the Role of Gender - A Case Study of Iranian French-Learners. International Education Studies, 9(12), 254. https:// doi.org/10.5539/ies.v9n12p254

Richey, R. C., Silber, K. H., \& Ely, D. P. (2008). Reflections on the 2008 AECT Definitions of the Field. TechTrends, 52(1), 24-25. https:/ / doi.org/10.1007/s11528-008-0108-2

Robin, B. R. (2015). The effective uses of digital storytelling as a teaching and learning tool. Handbook of research on teaching literacy through the communicative and visual arts, 2, 429-440.

Roblyer, M. D., \& Doering, A. H. (2006). Integrating educational technology into teaching (Vol. 2). Upper Saddle River, NJ: Pearson/Merrill Prentice Hall.

Roehl, A., Reddy, S. L., \& Shannon, G. J. (2013). The flipped classroom: An opportunity to engage millennial students through active learning strategies. Journal of Family $\mathcal{E}$ Consumer Sciences, 105(2), 44-49. https:// doi.org/10.14307/JFCS105.2.12

Rogers, E. M. (2004). A prospective and retrospective look at the diffusion model. Journal of health communication, 9(S1), 13-19. https://doi.org/10.1080/10810730490271449

Roschelle, J., \& Pea, R. (2002). A walk on the WILD side: How wireless handhelds may change computer-supported collaborative learning. International Journal of Cognition and Technology, 1(1), 145-168. https:/ / doi.org/10.1075/ijct.1.1.09ros 
Sallee, C. W., Edgar, D. W., \& Johnson, D. M. (2013). Student Perceptions of Instructional Methods towards Alternative Energy Education. Journal of Agricultural Education, 54(2), 130-142. https://doi.org/10.5032/jae.2013.02130

Schreiber, B., \& Dougherty, J. P. (2017). Embedding algorithm pseudocode in lyrics to facilitate recall and promote learning. Journal of Computing Sciences in Colleges, 32(3), 20-27.

Shuler, C. (2009). Pockets of potential: Using mobile technologies to promote children's learning.

Sorva, J., Karavirta, V., \& Malmi, L. (2013). A review of generic program visualization systems for introductory programming education. ACM Transactions on Computing Education (TOCE), 13(4), 15. https:// doi.org/10.1145/2490822

Sung, Y. T., Chang, K. E., \& Liu, T. C. (2016). The effects of integrating mobile devices with teaching and learning on students' learning performance: A meta-analysis and research synthesis. Computers $\mathcal{E}$ Education, 94, 252275. https:// doi.org/10.1016/j.compedu.2015.11.008

Tanes, Z., \& Cemalcilar, Z. (2010). Learning from SimCity: An empirical study of Turkish adolescents. Journal of adolescence, 33(5), 731-739. https:/ / doi.org/10.1016/j.adolescence.2009.10.007

Vanderlinde, R., \& van Braak, J. (2010). The e-capacity of primary schools: Development of a conceptual model and scale construction from a school improvement perspective. Computers $\mathcal{E}$ Education, 55(2), 541-553. https:/ / doi.org/10.1016/j.compedu.2010.02.016

Vanderlinde, R., \& van Braak, J. (2011). A New ICT Curriculum for Primary Education in Flanders: Defining and Predicting Teachers' Perceptions of Innovation Attributes. Journal of educational technology \& Society, 14(2).

Vlieghe, J. (2014). Education in an age of digital technologies. Philosophy \& Technology, 27(4), 519-537. https:// doi.org/10.1007/s13347-013-0131-x

Vogel, J. J., Vogel, D. S., Cannon-Bowers, J., Bowers, C. A., Muse, K., \& Wright, M. (2006). Computer gaming and interactive simulations for learning: A meta-analysis. Journal of Educational Computing Research, 34(3), 229243. https:/ / doi.org/10.2190/FLHV-K4WA-WPVQ-H0YM

Wang, R., DeMaria Jr, S., Goldberg, A., \& Katz, D. (2016). A systematic review of serious games in training health care professionals. Simulation in Healthcare, 11(1), 41-51. https:/ / doi.org/10.1097/SIH.0000000000000118

Watson, W. R., Mong, C. J., \& Harris, C. A. (2011). A case study of the in-class use of a video game for teaching high school history. Computers E Education, 56(2), 466-474. https:/ / doi.org/10.1016/j.compedu.2010.09.007

Weaver, G. C., \& Sturtevant, H. G. (2015). Design, implementation, and evaluation of a flipped format general chemistry course. Journal of Chemical Education, 92(9), 1437-1448. https://doi.org/10.1021/acs.jchemed.5b00316

Wrzesien, M., \& Raya, M. A. (2010). Learning in serious virtual worlds: Evaluation of learning effectiveness and appeal to students in the E-Junior project. Computers $\mathcal{E}$ Education, 55(1), 178-187. https:/ / doi.org/10.1016/j.compedu.2010.01.003

Xin, J. I. A. N. G. (2012). The Effect of Integrating Inductive Approach and Deductive Approach With Multimedia Assistance Into Acquisition of Subjunctive Mood. Sino-US English Teaching, 9(9), 1510-1515.

Young, J. (2004). When good technology means bad teaching: Giving professors gadgets without training can do more harm than good in the classroom, students say. The Chronicle of Higher Education, 51(12), A31-A37.

Yukselturk, E., \& Bulut, S. (2007). Predictors for student success in an online course. Journal of Educational Technology $\mathcal{E}$ Society, 10(2).

\section{http://www.ejmste.com}

